NORDISK MUSEOLOGI $1994 \cdot 1$, S. 75-82

\title{
LOKALMUSEER OG MUSEUMSPROFESJONALITET
}

\author{
John Aage Gjestrum
}

En av de viktige innfallsvinkler $i$ studiet av museene er deres rolle som humanistisk prosjekt $i$ samtida. I artikkelen vil vi se serskilt på hvordan arbeidet med et spesifikt lokalsamfunns innbyggere representerer en kvalitativ forskjell fra det a arbeide $i$ store museer overfor et anonymt publikum. Samtidig som de store museer blir stadig større, skjer det over hele verden en eksplosjon i tallet pa små museer. Disse museenes funksjon kan sees som knyttet til menneskets behov for historisitet og stedsfolelse. De viser at behovet for museer går langt lenger enn vitenskapenes behov, vitenskaper som stort sett har fätt vare alene om å definere museenes profesjonalitet.

I vår tid kan vi se at folkelig museumsarbeid fornyer museumsinstitusjonen. Vi ser at økomuseumsbegrepet og såkalt "ny" museologi utfordrer den tradisjonelle museumsprofesjonelles rolle. Museumsarbeidere må finne et nødvendig humanistisk grunnlag for at deres identitet også i museumsfagene og museumsinstitusjonene kan bli meningsfull $i$ de utfordringer den museumsprofesjonelle vil bli stilt overfor.

Et utgangspunkt $\mathrm{i}$ dagens samfunnssituasjon betyr at mange "gamle sannheter" har mistet sin gyldighet. De vekst- og utviklingsprognoser som preget modernismen, nådde sine høyepunkt på 1960- og 70-tallet. De er nå på 1990-tallet avløst av det mange karakteriserer som et etterindustrielt samfunn.

Etter en flere hundreårig tidsalder med ubrutt framskritts- og utviklingsoptimisme, er dette antakelig et langt mer dramatisk tidsskille enn vi umiddelbart kan oppfatte. Ikke minst legger det større humanistiske utfordringer på menneskeheten, som skal leve med et etisk ansvar i ei tid da mennes- ket har alle muligheter til total ødeleggelse.

\section{ET "BIG-BANG" I \\ MUSEUMSVERDENEN}

Da franskmannen Hugues de Varine ble bedt om å være den som skulle sammenfatte resultater og debatter ved ICOM's generalkonferanse i Quebec, Canada, i 1992, - var det ikke minst fordi han som direktør i ICOM på 1960-tallet og fram til 1974, nettopp den gang stod midt oppi intense fors $ø \mathrm{k}$ for å skape mer tidsmessige museer, og var en av få med et virkelig overblikk over det som da skjedde. Han 
76 stod sentralt $\mathrm{i}$ å bringe de utenomeuropeiske museene inn i ICOM. Han formulerte begrepet økomuseum i 1971, og la sammen med sin forgjenger i ICOM, Georges Henri Rivière, grunnlaget for mye av den museumstenkning som særlig på 1980 -tallet ble presentert under benevnelsen ny museologi.

Når han nå i 1992 på nytt forsøker å etablere et tilsvarende overblikk, er hans konklusjon at mens museumsverdenen for 20-30 år siden var en ensartet og svært godt definert verden, finner han nå denne tidligere nucleus i museums-institusjonene og museumsprofesjonen i en eksplosjonsprosess. De store museene blir stadig større og trenger mer og mer penger. Her finner han kunstmuseene og "show-museer" - alt i en retning av globalisering av kulturelle krefter, og i en ukontrollert bevegelse uten grenser. Samtidig finner han at tusener av museer skapes omkring i verden. Disse er av stadig mindre og mindre type, også dette en ukontrollert utvikling, gjennom manifestering av initiativer som blir lokalsamfunnets museer. Hugues de Varine sier han virkelig var sjokkert over radikaliseringen av debatten, og at denne big-banglogikken innebærer noe nytt og viktig:

Jeg kan se noe som ser ut til å være svært nytt for meg, som jeg ikke så for 20 år siden. Nødvendigheten av et konsept for å dele museene $\mathrm{i}$ to: prosessmuseet og institusjonsmuseet, som er en annen type museum. Jeg har på følelsen at et økende antall medlemmer i ICOM, enten de liker det eller ikke, skiller svært klart mellom institusjons-museet, - altså museumsinstitusjonen slik ICOM har representert den gjennom lang tid, - og en viss museumsprosess, som jeg navngir på denne måten fordi jeg ikke har et bedre ord. Arbeidet utenfor institusjonen synes å være preget av folk som ikke nødven- digvis nå er fagfolk. Men kanskje dette vil bli en seier for musene å være i stand til å komme ut av institusjonens grenser for å gi tyngde til viljen hos folk som ikke er museumsfolk fra starten. ${ }^{1}$

\section{STEDETS BETYDNING - TERRITORIALITET}

Lokalmuseenes funksjoner kan sees som knyttet til grunnleggende menneskelige behov, som menneskers behov for å kjenne og forstå det sted der de kanskje tilbringer mesteparten av sitt arbeids- og sosiale liv. Bare ved slik forståelse kan enkeltmennesket ta stilling vis-a-vis fortida og de prosesser som har påvirket stedet og menneskene der. Ved å ta posisjon utvikles grunnlag for fellesskap og samhandling, for at menneskene kan bli aktører $\mathrm{i}$ verden, ikke bare tilskuere. I dette ligger viktige forutsetninger for at demokratier kan nå sine målsettinger.

Hjemstedet $\mathrm{i}$ det moderne industrisamfunnet har for mange først og fremst vært oppfattet som et sted stadig å reise fra, i tråd med målsettinger om optimal mobilitet. Det har derfor vært ønsket å knytte "irrasjonelle" følelser, nostalgi og romantikk til hjemstedet, mer enn empiri og dypere basert kunnskap.

En forsker som har brutt med den overflatiske likegyldigheten omkring hjemstedets betydning og det å bo, er den norske arkitekturprofessoren Christian NorbergSchultz. Han vektlegger sammenhengen mellom det å kjenne et sted, hvordan denne tilhørigheten på samme tid er noe helt personlig knyttet til individet, samtidig som stedet oppleves som noe en har sammen med andre, og som derved blir grunnlag for felleskap eller samfunn. $\AA$ bo er derfor kvalitativt sett noe langt mer enn 
materielle og kvantitative spørsmål, slik vi kjenner det fra mye av 1960- og 70-tallets moderne planlegging:

Det å bo i denne kvalitative forstand er et grunnleggende trekk ved det å være menneske. Det er først og fremst gjennom identifikasjon med et sted at vi vier vårt liv til en bestemt slags tilværelse. Derfor krever det å bo både noe av oss selv og av våre steder. Vi må ha et åpent sinn, og stedene må være slik at de byr på rike muligheter for identifikasjon. I dag er mange steder fattige og mange sinn lukket, og det er blitt vanlig å snakke om en omverdenskrise ${ }^{2}$.

Norberg-Schultz kaller dette stedstap. En svensk forsker som har arbeidet mye med menneskenes forhold til rommet i lokalt og regionalt perspektiv, er kulturforskeren $\mathrm{Per}$ Råberg. Med bakgrunn i en kritikk av den rasjonalistiske holdningen som har preget store deler av 1900-tallets arkitektur og samfunnsplanlegging, formulerer han et teoretisk grunnlag for en tese om at mennesket på tross av vår naturstridige oppførsel som gruppe, likevel som individer er av en grunnleggende økologisk natur, og at mennesket trenger avgrensede økologiske rom å etablere en trygghet innenfor. Råberg definerer flere økologiske rom som responderer til ulike grunnbehov i forhold til private, kollektive og offentlige funksjoner, og peker på at det konkrete budskapet $\mathrm{i}$ hans teori

... är att det ekologiska rummet inte bara uppfattas som ramar kring sociala och ekonomiska livsfunktioner. Det representerar en egen - holistisk - dimension och är ett mål för individens strävan till estetisk identifikation med omvärlden som en upplevelsemässig helhet. ${ }^{3}$

Den kinesisk-amerikanske geografen $Y i$ Fu Tuan la i 1974 fram sitt begrep topofili: av gresk topos - plass og filos - venn.
Topofili berører derfor menneskets stedbundethet, - knyttet til følelsesmessige, viljemessige og fornuftsmessige bånd. ${ }^{4}$ I den følelsesmessige tilknytningen til et sted, som ofte kan være hjemstedet, ligger motiveringer for å ta vare på kultur og natur på dette stedet. Noe som ofte vil stå i kontrast til modernismens rasjonalitet, der naturen er råstoff for produksjonen, og der evt. "verneverdige" deler av kultur og natur som kommer i veien, kan bringes til redning på egnede, nødvendige reservater.

Et annet begrep som kan brukes i denne sammenheng er territorialitet - som knytter seg til hvordan mennesket forstår rommet, det landskap det lever i. Mens territoriet er et nøytralt geografisk begrep, kan territorialiteten sees som de idéer, den mentale forståelse menneskene $\mathrm{i}$ et område har om forholdet mellom seg og sitt territorium. Denne territorialiteten vil idag være kvalitativ målt ut fra hvorvidt menneskenes og lokalsamfunnets forståelse vil føre til en ødeleggelse av det framtidige livsgrunnlag eller en bevaring av det.

Sagt på en annen måte: en følelsesmessig og kunnskapsmessig bevissthet og nærhet til et sted, den plass en bor på, vil antakelig være viktig for å etablere økologisk ansvarlige handlinger. Territorialiteten uttrykker noe om forholdet mellom menneskene og moder jord, - et kritisk tema i vår tid.

\section{TID OG HISTORISITET}

Mens tredimensjonalitet er en måte den fysiske verden, stedet, oppleves på i et bestemt tidsøyeblikk, er den fjerde dimensjonen tiden. Det er ved å se firedimensjonalt at en ser et sted slik at også endringsprosesser inngår i karakteristikken. Den engelske forskeren Kevin Walsh peker i si 
John Aage GJestrum

78 bok om museenes framstilling av fortida, på hvor viktig det er å slå fast at det ikke er noen ontologisk forskjell mellom forti$\mathrm{da}$ og nåtida. Om vi anser vår nåtid som kontinuerlig å bli konstruert i "fortida" eller alltid i "nåtida", er ikke det avgjørende. Det viktige er at vi innser at endringsprosessene gjennom tid og rom er kontinuerlige, og at studiet av og bevisstheten om ens eget nåtidige sted ikke er forskjellig fra studiet av dets fortid. ${ }^{5}$

Det behov menneskene har for historisitet er noe annet enn vitenskapsmenns behov for å "redde" kunnskapen om forti$d a$. For forskeren er det viktige å finne ut ny kunnskap om historia, å se sammenhenger og oftest vektlegge det som er "rikshistorisk" interessant. Den samme forskeren vil imidlertid kunne ha liten evne til å forstå at for enkeltmennesket, er det ikke akkumuleringen av ny historisk kunnskap som er verdifull, men etableringen av en historisitet, - av sjøl å være i historia, i en sammenheng mellom det som var, det som er og det som skal bli.

Hvis en i museene kan forholde seg til fortida som historikere, og være $\mathrm{i}$ nåtida som kulturarbeidere, hvilken rolle er en i når og hvis en forholder seg til framtida? Jean-Paul Sartre formulerer i sin eksistensialisme et perspektiv som er viktig for forståelsen av museets og museumsarbeiderens rolle, når vi skal prøve å svare på dette.

Menneskets eksistens er ikke statisk, men blir hele tida til. Individets står i sammenheng med sin fortid, men er ikke absolutt determinert av den. Dets tanker, valg og handlinger, - altså dets væren $\mathrm{i}$ nåtida, - bestemmes like mye av bevisstheten om framtidige muligheter.

Ifølge Sartre projekterer mennesket hele tiden sine framtidige eksistensmuligheter, ja i en forstand "er" mennesket disse mulighetene. [...] Mennesket er nå ikke lenger det det har vært (i fortiden) og det er nå det det ennå ikke er (blitt i framtiden). Enklere: Mennesket er ikke sin fortid, det er sin mulige framtid. ${ }^{6}$

Hva betyr dette for museet? Vi blir nødt til å akseptere museet som et humanistisk prosjekt. For humanisme innebærer vel nettopp denne muligheten, denne friheten til handling. Handlingene her kan være nettopp utvalget av hva fra fortida som skal gjøres talende i museet, - det kan være å engasjere seg i viktige miljøspørsmål, - det kan være å velge å la alt være eksakt slik det har vært ...

Uansett hvilket valg en tar, så skjer det som et valg, der det eksisterer reelle friheter til å velge annerledes. I dette ligger en etisk utfordring for alle som arbeider med museer. Dette påvirker museets funksjon i nåtida, det påvirker framstillingen av fortida, og det er en del av samfunnets omforming. Kort sagt, museet kan ikke gjemme seg unna sin politiske funksjon.

\section{"NY» MUSEOLOGI OG ØKOMUSEER}

Mot slutten av 1960-tallet var det erkjent i mange land at museene hadde kommet $\mathrm{i}$ ei krise. Løsninger på dette ble prøvd ut gjennom satsing på ny arkitektur og mer offensive formidlingsteknikker brukt på det "gamle" innholdet, - ny teknologi som audiovisuelle media, osv.

En annen innfallsvinkel var en omdefinering av museumsinstitusjonens karakter. Dette skjedde f.eks. ved Santiago-konferansen i Chile 1972, der museets sosiale rolle i Latin-Amerika ble institusjonalisert i konseptet for det integrerte museum. I LatinAmerika var kanskje kontrasten mellom den 
sosiale virkelighet og museenes rolle som underholdning for en liten, men mektig økonomisk og politisk elite, mer brutalt tydelig enn noe annet sted. Det skjedde på denne tida også andre ting som f.eks. etableringen av neighbourhood-museums i USA.

Økomuseene i Frankrike skulle bli det som tydeligst fokuserte museenes inntreden i den nye miljøalderen. Georges Henri Rivières definisjon av økomuseet fra 1972 er idag et historisk dokument, selv om den ennå har aktualitet:

\section{Økomuseet: - et spesifikt museum for miljøspørsmål}

Ethvert museum som er etablert $i$ et landlig eller urbant miljø, og som legger vekt på denne dimensjonen, er bedt om:

a. $\AA$ gjennomføre et intensivt studium av dette miljøets utvikling $\mathrm{i}$ et tverrfaglig perspektiv, slik at det omfatter både de kulturelle og naturmessige sider av det.

b. Å opprette samlinger og arkiver av dokumenter om dette miljøet, enten ved hjelp av museets egen dokumentasjon eller fra andre kilder

c. $\AA$ etablere en innsamlingspolitikk av dokumentasjon representativ for dette miljøet, utfra topologiske eller økologiske kriterier.

d. Å formidle og gjøre tilgjengelig den dokumentasjonen som museet har samlet inn, enten i form av permanente, temporære eller oppsøkende utstillinger, eller ved hjelp av audiovisuelle hjelpemidler og bruk av massemedia.

e. Stimulere den lokale befolkningen til å delta $\mathrm{i}$ museets virksomhet og til å bli engasjert i vern og utvikling av miljøet.

f. Denne aktiviteten bør foregå både innenfor museets vegger og utenfor $\mathrm{i}$ nær kontakt med de som lever i miljøet.

På denne måten vil en ny museumstype bli skapt og som fortjener å bli kalt økomuseum, et møtested for de som er aktive og påvirker miljøet, de som utsettes for det, og de som studerer det. ${ }^{7}$
I Frankrike ble økomuseumsbevegelsen på 79 1970-tallet et kraftig uttrykk for en museumskritikk, og en rekke økomuseer ble til. Lokalbefolkningen som aktør i nåtida innenfor et avgrenset territorium stod i sterk kontrast til de "gamle" museenes generelle budskap til et ikke-definert og anonymt publikum. Det internasjonalt mest kjente eksemplet ble Le Creusot, - et gammelt industristed ca. 40 mil sør for Paris.

Hugues de Varine oppsummerte i 1986 funksjonene til det han da kalte lokalsamfunnsmuseet som firedelt: (1) å være databank, (2) å tjene som observatorium, (3) å være et laboratorium, og (4) å være et utstillingsvindu, der en kan "vise sine skatter fra fortida, sin bekymring om nåtida, sine planer og prosjekter for framtida". ${ }^{8}$

Økomuseumstankene kom gradvis også inn i andre land, som f.eks. Québec (den fransktalende del av Canada), Portugal, Spania og etterhvert også i Skandinavia. Idag er det over hele verden ca. 90 museer med økomuseumsbetegnelsen i navnet, mens et mangedobbelt tall av museer arbeider i tråd med økomuseumskonseptet under navn som museo communitario, community museums.'

Ut fra økomuseumsmiljøet vokste det så fram et miljø under begrepet ny museologi som fanget inn en videre museumskritikk enn bare økomuseumsfenomenet. I 1984 organiserte ei gruppe museumskolleger fra hele verden MINOM, - International Movement for a new Museology, som en organisasjon tilsluttet ICOM. I 1986 holdt MINOM sitt 3. internasjonale arbeidsseminar på Toten i Norge. I 1992 ble det arrangert en nordisk økomuseumskonferanse på Samsø i Danmark. ${ }^{10}$

Det er ikke vanskelig å se likhetspunkter mellom det eldre folkelige museumsarbeidet 
John Aage Gjestrum

80 i Norden og den nye museologien. Rivière var da også klart inspirert av folkemuseene. Samtidig er det åpenbart at en i vår tid møter utfordringer av et helt annet slag:

Museene må ta del i å møte miljøproblemenes utfordringer ut fra den økologiske forståelseshorisont, fordelingsspørsmål - ikke bare innenfor nasjonen, men også globalt, sammen med spørsmålene om humanistiske grunnverdier og menneskerettigheter.

$\varnothing$ komuseet plasserer seg her som et kulturpolitisk instrument både i lokalsamfunnet, - der menneskene faktisk lever, - og i det globale verdenssamfunnet, der enkeltmennesket er tildelt et medlemsskap som ikke kan sies opp.

\section{TEMPEL OG FORUM}

"Våre museer trenger desperat til psykoterapi, - de er i en identitetskrise og vet ikke hvem eller hva de er", skrev den kanadiske museumsmannen Duncan Ferguson Cameron som innledning i 1971 til sin i ettertid berømte artikkel The Museum, a Temple or the Forum. ${ }^{11}$

Han grep fatt i museenes problemer med å definere sine roller. De tradisjonelle museer ble til som templer der en vernet om det samfunnets elite regnet for viktig og verdifullt. Det museet sa, var uttrykk for sannhet. Museet var stedet en kunne gå for å sammenligne egen oppfatning av virkeligheten med et objektivt syn på virkeligheten, som var akseptert og anbefalt av ens eget samfunn.

Cameron så et viktig og preserende behov for en re-etablering av forum som en institusjon i samfunnet, - forum for konfrontasjon, eksperimentering og debatt. I museenes identitetskrise kan mange institusjoner ikke bestemme seg for om de ønsker å være museum som et tempel, eller ønsker å bli et offentlig forum. Noen har prøvd å bringe et forum inn i tempelet. Dette er å kastrere opptreden i forum, og skjer oftest som paternalisme, en måte å ta inn antiestablishment inn i de etablerte institusjoner for derved å nøytralisere fienden, sier Cameron i 1971.

.... forum er hvor slagene skal kjempes, tempelet er der vinnerne hviler. Det første er prosess, det andre er produkt. ${ }^{12}$

\section{KONKURRERENDE IDENTITETER}

Når Duncan F. Cameron 20 år senere igjen formulerer et kritisk perspektiv på museene og den virkelighet de opptrer $i$, er hans første erkjenning det at endringene vi vil bli vitne til $\mathrm{i}$ vår egen tid, vil bli av et kollossalt omfang, og stille de som arbeider i museumsverdenen overfor enorme utfordringer. Han observerer derimot at de færreste tar imot utfordringene, de spiller heller "safe". ${ }^{13}$

De eksempler som jeg ser på fast handling og engasjement overfor nye synsmåter er for isolerte og ofte av kort levetid. $\mathrm{Og}$ enda værre er det når jeg ser at de sterke og overbevisende eksemplene på engasjement for endring blir feiret av forsvarerne for status quo, som bruker det bisarre, bakvendte argument om at ett godt eple gjør hele tønna god. ${ }^{14}$

Cameron spør om museumsfolkene kan danne en del av avantgarden for positiv sosial endring? Han tror det er mulig, ikke minst hvis en innser betydningen av det kompleks han kaller den ikke-hellige treenighet. I dette legger han at det ikke bare er ulikheter i syn på politikk, prioriteringer eller taktikk alene som kompliserer oppga- 
ven, men at det også er ulike verdier innen oss selv som står i konflikt til hverandre, og som kan skape smertefulle dilemmaer. De museumsprofesjonelle utgjør en ikkehellig tre-enighet av private, profesjonelle og institusjonelle personer.

Kan en leve som enkeltmenneske (privatperson), fagutøver (profesjonsperson) og knyttet til en museumsinstitusjon (institusjonsperson) med helt ulike verdier og moraloppfatninger for hver av disse rollene? Betyr det i så fall at en bevisst eller ubevisst undertrykker en eller to av rollene til fordel for den tredje? Hva som da vil lide kan være ulikt. Cameron peker på at for det private og profesjonelle nivå må hver en av oss svare for oss selv på spørsmålene. Når det gjelder institusjonene som vi spør på vegne av, er det en økende ubehagelig status quo som er i fare, og ikke noe mindre enn overlevelsen som står på spill.

Det er en ny følsomhet og åpenhet for proposjonene for endringer som vi trenger, mye mer enn vår tilvante ensidige tilbøylighet for intellektualisering. [.... Dette er en anmodning om en uhemmet reeksiminasjon av oss selv, våre museums-profesjoner, og mest av alt av museet som institusjon. ${ }^{15}$

Skal vi forstå museumsinstitusjonene, må vi forstå hvordan de har startet. Vi må utforske begynnelser, dette vil også være starten på studiet av endringer. Cameron vil lage utstillinger med spørsmål som søker etter svar istedet for svar som skal møte spørsmålene. Han vil at museene skal bli et sted for utprøving, eksperimenter, debatt og for motsetninger. Mandatet er ikke lenger å forsvare troen, å være den siste hersker over smaken eller det faderlige forbilde av kulturell korrekthet, slik museene for ofte har vært i fortida.
Den museumsprofesjonelles oppgave vil knyttes til spørsmål om hjertet, om innstillinger og følelser. Ut fra dette former Cameron visjonen av det nye museets forum:

Vi er forlatt stående på trappene til det nye forum som kan komme, uten løfter eller faste retninger å bevege seg i. Når jeg forsøker å visualisere status quo som rom, finner jeg at vi er $\mathrm{i}$ et stort, rektangulært rom, med perfekte proposjoner, med solide vegger og en dør som fører ut. Den er lukket. Når jeg forsøker å se rommet til status fluctus, som jeg tror er den sanne karakter for denne tidsalder, er vi i en stor, luftig rotunda, med portaler rundt det hele som åpner mot de morgendager som kan bli. ${ }^{16}$

\section{SUMMARY}

\section{Local museums and professionalism in museums}

Today there are several reasons to stress the importance of local museums. At the same time we find big museums growing even bigger and observe an explosion in the number of small museums all over the world . The former ICOM director Hugues de Varine calls this a big-bang in the museum world, which makes it necessary to separate museums in two very different types: the process-museum and the institutionmuseum, the latter being the traditional museum.

In understanding this new museum process, it is important to know how the scientific needs and basics of the traditional museum differ from many of these process-museums, which are founded on the population's need to understand their territory, territoriality, - and of being connected to their local history. This need of historicity is different from the professional historians' research aiming at new knowledge. The existentialism of Jean-Paul Sartre gives some important perspectives in understanding the importance of history, and how man always has to liberate himself from his past. The choices in the pre- 
82 sent are partly determined by the past, and partly by the visions of a possible future.

The ecomuseums, first established in France about 1970 , afterwards in many parts of the world, have expressed a strong criticism of the "old" museum. The local population as an actor in the present within a limited territory, forms a strong contrast to the traditional museum with its general message to a non-defined and anonymous public.

In 1971 the Canadian museologist Duncan F. Cameron pointed out the museum's need to develop both the functions as a temple and as a forum. Twenty years later he once more offers a critical analysis of the museum and the museum profession. Cameron still thinks the museum profession can form part of the vanguard for positive social change. One of the biggest problems, he finds in the conflicting values within the individual, who is constituted as an unholy trinity of private, professional and institutional persons. Each professional person will have to re-examine himself, the academic disciplines and the museum institution. To meet the challenges of tomorrow it is necessary with a change of heart, not only intellectualism.

\section{NOTER}

1. Hugues de Varine, "'Big Bang' i museumsverdenen", Museumsnytt 1992:4, 26

2. Christian Norberg-Schulz, Mellom jord og himmel (Oslo, 1992), 14

3. Per Råberg, "Ekologi och estetik", Magasin Tessin 1985:2-3, 126, se også Per Råberg, The Space of Man (Stockholm, 1987)

4. Referert her fra Johan Asplund, Tid, rum, individ och kollektiv (Stockholm, 1983), 169-170

5. Kevin Walsh, The Representation of the Past. Museums and heritage in the postmodern world (London og New York, 1992), 148-159

6. Sitert fra Espen Schaanning, Modernitetens opplosning (Oslo, 1992), 47-48

7. Hugues de Varine, "Om økomuseet", opprinnelig trykt i La Gazette 11:2 (Montréal, 1978), oversatt og trykt i John Aage Gjestrum og Marc Maure, eds., Økomuseumsboka, - identitet, økologi, deltakelse (Tromsø 1988), 107. Se også oversatt til svensk den siste verson Rivière utarbeidet, trykt i Svenska Museer 1986:4-5, 32

8. Hugues de Varine, "Rethinking the museum concept",. i Gjestrum/Maure, 33-40

9. Se temanummeret: "Images of the Ecomuseum". Museum 37:4 (Paris, 1985), Karp, Kreamer \& Lavine, eds., Museums and Communities.(Washington, 1992), og René Rivard, Opening up the museum - towards a new museology, stensil (Quebec, 1984). I Svenska Museer se nr. 1985:3 og 1986:2-3. Se også: Per-Uno Ågren, "Internationella perspektiv". i Museiperspektiv, 49-60

10. Se Traditions et perspectives nordiques: du musée de plein-air à l'ecomusélles minorités des régions artiques. Rapport med foredragene fra Minom-konferansen (Toten, 1986), og Lis Nymark \& John Resshaur, eds., Rapport fra det forste Nordiske

Økomuseumsseminar (Samsø, 1992). Se også:

Kenneth Hudson, "The dream and the reality. Kenneth Hudson discusses 20 years of ecomuseums and ecomuseology", Museums Journal, april 1992, s. 27-31, og John Aage Gjestrum, "Fra folkemuseum til økomuseum", Heimen 1993:1, 30-45

11. Duncan F. Cameron, «The Museum, a Temple or the Forum", Curator 1971:1, 11-24

12. Cameron (1971), op.cit., 21

13. Duncan F. Cameron, "A Change of Heart", Museum Management and Curatorship 1992, vol. $11,375-386$

14. Cameron (1992), op.cit., 377

15. Cameron (1992), op.cit., 378

16. Cameron (1992), op.cit., 386

John Aage Gjestrum er norsk forskningsrådsstipendiat i museologi, knyttet til Institutionen for museologi, Umeå universitet. Arbeider med doktoravhandling med tema "Museum, kulturarv og lokalsamfunn". Adr: N-2846 Bøverbru, fax +47-61196013 